\author{
E. Sheveleva ${ }^{1}$, S. Shevelev ${ }^{1}$, A. Sokolovskiy ${ }^{2}$, A.K. Zeinidenov ${ }^{3}$ \\ ${ }^{1}$ National Research Tomsk Polytechnic University, Tomsk, Russia; \\ ${ }^{2}$ University of Washington, WA 98195 Seattle, United States; \\ ${ }^{3}$ Ye.A. Buketov Karaganda State University, Kazakhstan \\ (E-mail: wevelev@tpu.ru)
}

\title{
Investigation with using thermal analysis of gas evolution and sintering of nanopowders of zirconia prepared by sol-gel method
}

\begin{abstract}
Thermal and XRD analyses were used to study partially stabilized zirconia powders produced by sol-gel method in order to investigate gas evolution in annealing in air and densification behavior of these powders in compaction and subsequent sintering. It was found that the powders of the initial gel contain a large amount of gas adsorbates. The amount of adsorbates decreases as the annealing temperature grows. At annealing temperature of $700{ }^{\circ} \mathrm{C}$, adsorbates are completely removed from the powders and the latter obtain a crystalline structure with a predominant tetragonal phase. Gas adsorbates affect densification of powder compacts during sintering and facilitate the production of ceramics with a porosity of not more than $5 \%$. It is shown that the production of low porosity ceramics is complicated even though powders subjected to annealing may contain nano-sized impurities or be free of these. Low-melting additives are proposed to be used for ceramics production.
\end{abstract}

Keywords: nanopowders of zirconia, sol-gel method, gas adsorbates, dilatometry.

\section{Introduction}

Zirconia-based ceramics is a commonly used material [1-4]. The starting product for its production is zirconia powders [5] doped with stabilizing additive, for example, yttrium oxide, to improve its strength properties $[6,7]$. The smaller the sizes of the powders, the better the mechanical properties of the ceramics produced from the powders $[8,9]$. Utra-fine powders open up new opportunities for the production of nanosized ceramics. Different methods are used to produce zirconia powders. The most common methods used for commercial production are plasma-chemical [10-12] and sol-gel [13-16] synthesis methods. There are a number of other methods to produce ultra-fine or nanopowders, but they are typically low productive. These methods include, for example, evaporation of the initial substance through heating by laser radiation $[17,18]$ and electron beam [19]. Due to complexity and low productivity, these methods are mainly used to produce small amounts of powder for scientific purposes.

The features of the powder preparation process in plasma-chemical synthesis ensure the formation of ultra-fine particles, with a significant part of the particles attaining less than $100 \mathrm{~nm}$ in size [20]. At the same time, most of the particles are more than $100 \mathrm{~nm}$ and up to $1 \mu \mathrm{m}$ in size. The powders are classified as ultrafine ones due to this particle size distribution. Powder particles prepared by plasma-chemical method have the form of hollow spheres or products of their mechanical destruction [21], which complicates the production of high-quality ceramics.

In contrast to the plasma-chemical method, sol-gel synthesis can be used to produce stabilized zirconia powders with particle size not exceeding $50 \mathrm{~nm}$, and these powders are classified as nanopowders. It should be noted that the sol-gel method ensures highly homogeneous chemical composition of the powder masses. The sol-gel method implies two technological processes: production of sol and its modification into gel. As a result, a colloidal system is formed in which the particles of the liquid disperse medium are enclosed in a flexible but sufficiently strong spatial stack formed by the bound particles of the disperse phase. The final stage of the powder preparation is drying the resulting stable gel.

The sol-gel method is highly productive and environmentally friendly, which makes it promising for commercial production of nanopowders $[22,23]$. The nano-sized powders produced by this method have a large specific surface and show high sorption ability. These powders can adsorb various gases and chemical compounds both at the stage of precipitation from the solution and at the drying and annealing stages. The role of sorption processes increases as the size of nanopowder particles reduces. Therefore, sorption process- 
es become an important consideration in the development of technologies to produce ceramics from these powders.

The purpose of this paper is to study nanopowders of stabilized zirconia prepared by sol-gel method in order to identify the patterns of gas evolution in thermal annealing in air and densification behavior in compacting and sintering under different conditions and modes of preliminary heat treatment of the initial powder masses using the methods of thermal analysis.

\section{Experimental}

Partially stabilized zirconia powders of $\left(\mathrm{ZrO}_{2}+3 \mathrm{~mol} \% \mathrm{Y}_{2} \mathrm{O}_{3}\right)$ composition were prepared by the chemical method of coprecipitation of zirconium and yttrium hydroxides from aqueous solution of zirconium and yttrium salts: zirconyl nitrate dihydrate $\mathrm{ZrO}\left(\mathrm{NO}_{3}\right)_{2} \times 2 \mathrm{H}_{2} \mathrm{O}$ and yttrium nitrate hexaqua $\mathrm{Y}\left(\mathrm{NO}_{3}\right)_{3} \times 6 \mathrm{H}_{2} \mathrm{O}$ by adding $25 \%$ aqueous ammonia solution up to $\mathrm{pH}$ 9.5. The hydroxide mixture was washed and dried at $100^{\circ} \mathrm{C}$ for 24 hours, and then it was annealed at temperature not exceeding $700{ }^{\circ} \mathrm{C}$. The annealing time was 1 hour.

The studies were carried out for initial powders produced by sol-gel method without annealing (type $\mathrm{P} 1$ ) and for powder $\mathrm{P} 1$ annealed in air at $400{ }^{\circ} \mathrm{C}$ (type $\mathrm{P} 2$ ) and $700{ }^{\circ} \mathrm{C}$ (type $\mathrm{P} 3$ ). The heating rate for powders $\mathrm{P} 2$ and $\mathrm{P} 3$ was $20^{\circ} \mathrm{C}$ per minute, and the isothermal holding time was 1 hour. The BET analysis of the produced powders was performed using the Sorbtometer-M instrument.

Powder compacts were prepared by uniaxial static pressing using a PGR-10 hydraulic press. The compaction pressure varied within 70-960 MPa. Ceramics was sintered in a dilatometer oven DIL 402C (NETZSCH, Germany) in air. The air blow rate was $20 \mathrm{ml} / \mathrm{min}$. Electron microscopy was carried out with a scanning electron microscope JEM-2100 (Japan). The XRD analysis was performed by means of an ARL'xtra diffractometer using a semiconductor Si(Li) Peltier detector monochromatized with $\mathrm{CuK} \alpha$ radiation. The diffraction patterns were measured in the range of angles $2 \theta=(90-120)^{\circ}$ at a velocity of $0.02^{\circ} \cdot \mathrm{s}^{-1}$. The XRD analysis was performed using the PDF-4+ powder database of the International Center for Diffraction Data (ICDD). The diffraction patterns were processed by full-profile Rietveld method using the Powder Cell 2.4 software. The density and porosity of the ceramic samples were determined by hydrostatic weighing in distilled water using a Shimadzu AUW-220 D balance supplied with special attachment. Microhardness was measured using a ZHV1M microhardness meter (Zwick, Germany). Thermal analysis of the powders was performed using a synchronous thermal analysis instrument STA-449 combined with a QMS 403 D mass spectrometer (NETZSCH, Germany).

\section{Experimental results and discussion}

Investigation of the microstructure. Electron microscopy of powder P3 is presented in Figure 1. Figure 1 shows that powder $\mathrm{P} 3$ of partially stabilized zirconia produced by annealing at $700{ }^{\circ} \mathrm{C}$ is nano-sized. The average particle size is $20 \mathrm{~nm}$. The maximum size does not exceed $30 \mathrm{~nm}$.

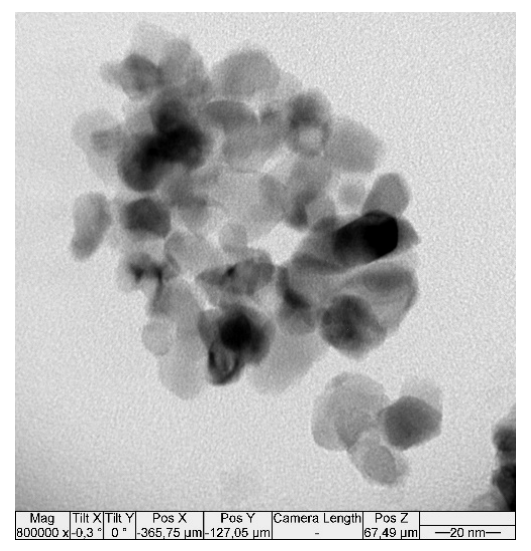

Figure 1. Electron microscopy of powder P3

Sufficiently clear rings observed on the electron diffraction pattern (Fig. 2) indicate that particles are nanocrystallites. 


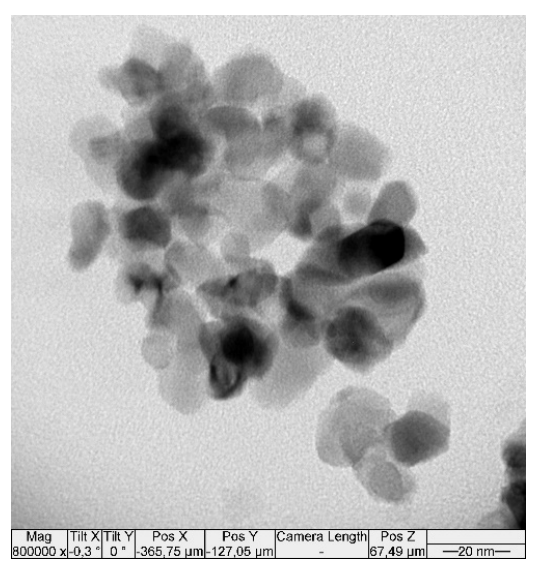

Figure 2. Electron-diffraction pattern for powder P3

The XRD data show that powder P1 is amorphous, while in samples P2 and P3 a tetragonal phase predominates. Figure 3 shows the diffraction pattern for powder $\mathrm{P} 3$ as an example. The parameters of the crystal lattice are as follows: $a=b=3.6282 \AA, c=5.1725 \AA, L=12 \mathrm{~nm}, \Delta d / d=2.3 \cdot 10^{-3}$. The diffraction pattern for powder P2 is similar to that for powder P3. The crystal lattice parameters for this powder are as follows: $a=b=3.6300 \AA, c=5.1790 \AA, L=8 \mathrm{~nm}, \Delta d / d=5.0 \cdot 10^{-3}$.

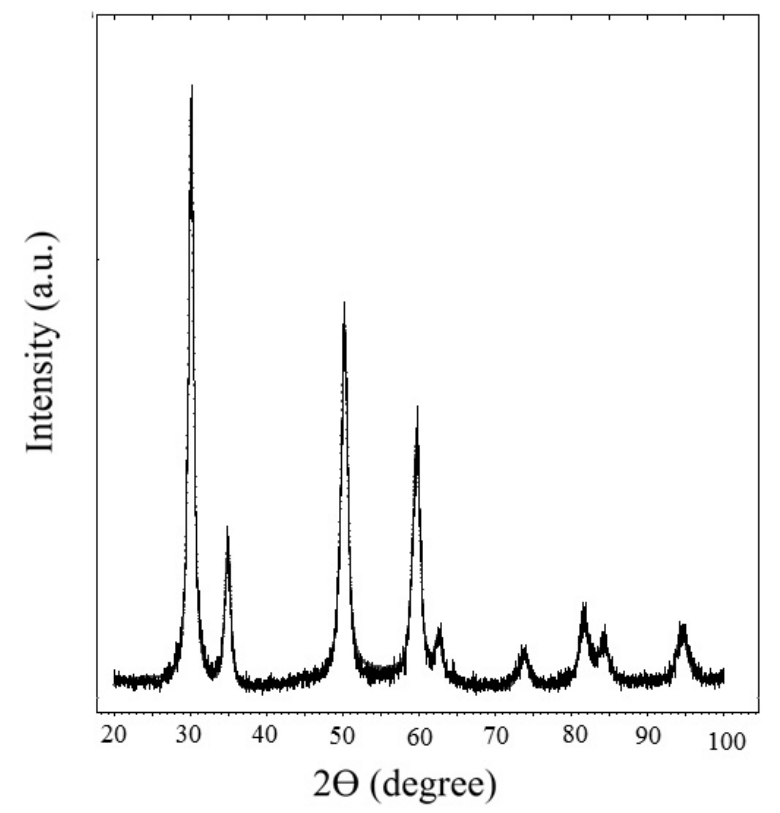

Figure 3. Diffraction pattern of the P3 powder compact made from stabilized zirconia powder annealed at $700{ }^{\circ} \mathrm{C}$

The results of BET analysis showed that the specific surface area of powder P3 is not less than $50 \mathrm{~m}^{2} / \mathrm{g}$. A large specific surface area causes high sorption activity of the powders produced. The presence of a large amount of adsorbed gases is evidenced by mass spectrometry data. Figures 4 and 5 show the results of the thermal analysis combined with mass spectrometry for powder P1 heated in air at a heating rate of $10{ }^{\circ} \mathrm{C} / \mathrm{min}$. Figure 4 indicates changes in the weight of powder sample P1 as temperature increases. As can be seen, heating is a two-stage process that results in the total weight loss of $25.81 \%$. The first stage occurs at a temperature of up to $400{ }^{\circ} \mathrm{C}$ due to endothermic reactions and is accompanied by volatilization of gas components with $m / z=17,18$ and 44, which are likely to correspond to $\mathrm{NH}_{3}, \mathrm{CO}_{2}$ and $\mathrm{NO}_{2}$. At the second stage, the gas components with $m / z=30$ and $46\left(\mathrm{NO}\right.$ and $\left.\mathrm{NO}_{2}\right)$ are evolved from the sample at temperatures ranged from 400 to $600^{\circ} \mathrm{C}$, which is accompanied by heat release. 


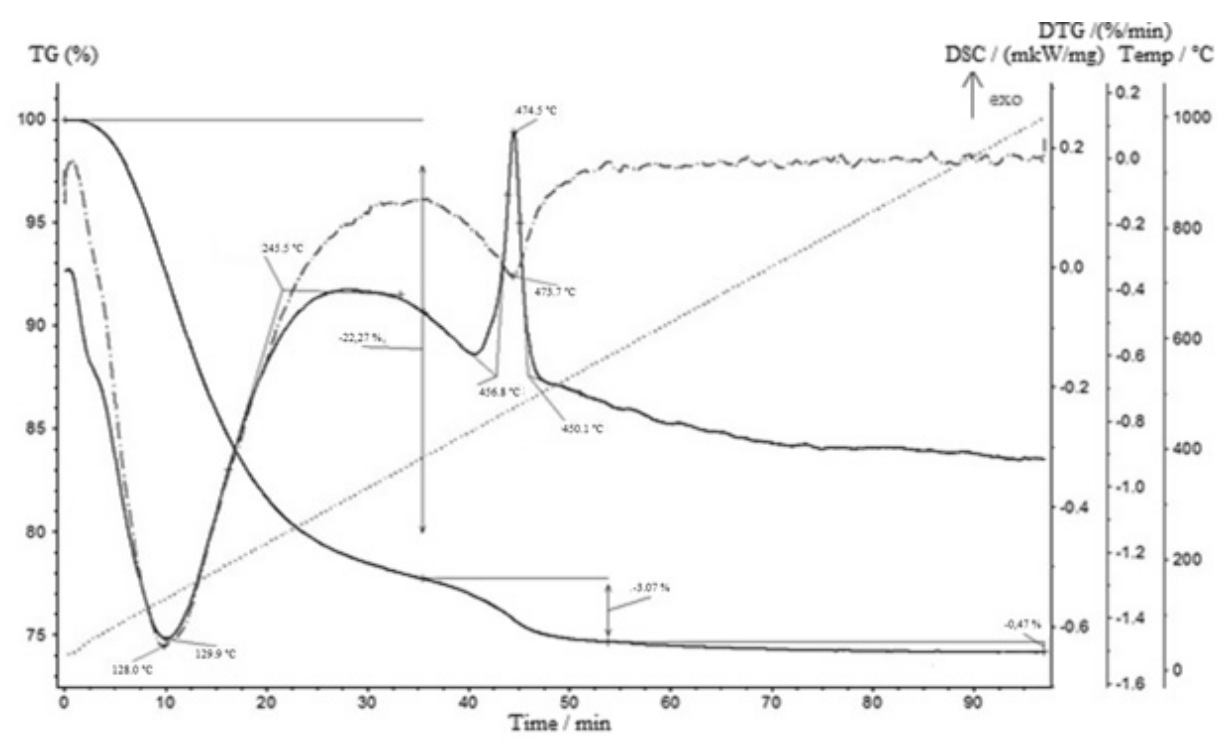

Figure 4. TG, DTG and DSC curves for sample P1

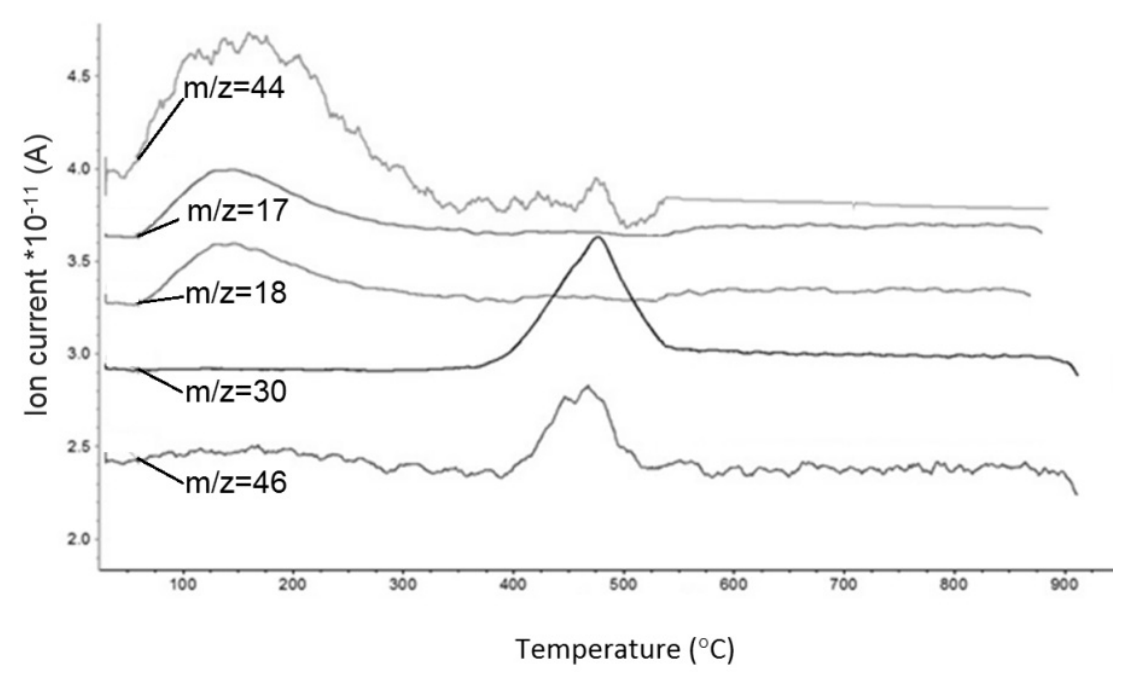

Figure 5. MS curves for sample P1

Shrinkage curves for compacts made from powders P1, P2 and P3 are presented in Figures 6-9. Figure 6 shows that the curve shape depends on the powder type. For initial powder (P1), shrinkage is intensive at low temperatures (Fig. 6, curve 1). According to Figures 4 and 5 is due to the reduced volume of the powder compact as a result of the evolution of a large amount of gas adsorbates during sintering. As can be seen in Figure 6, the shape of shrinkage curves 2 and 3 for compacts made from powders P2 and P3, respectively, is almost similar to the shape characteristic of ceramic sintering. The nature of shrinkage as a whole, especially in the region of isothermal holding, depends on the compaction pressure. At the same time, the samples made from powder P1 expand in this temperature region at high pressures (Fig. 6, curve 1; Fig. 7, curve 3). This phenomenon can be interpreted as follows. Increased pressure creates a denser compact and hinders the evolution of gas adsorbates during heating. When the temperature of isothermal holding attains $1400^{\circ} \mathrm{C}$, closed pores are formed. The residual gases in the pores increase the pore volume due to thermal expansion, which increases the volume of the ceramics sintered. The validity of this assertion is confirmed by data in [24], which investigates the effect of low-melting bismuth oxide additives on sintering of zirconia ceramics. In compacts made from powders $\mathrm{P} 2$ and $\mathrm{P} 3$, the expansion of ceramics at the isothermal stage is not observed, since the compacts contained a smaller amount of gas adsorbates (Fig. 4 and 5). 


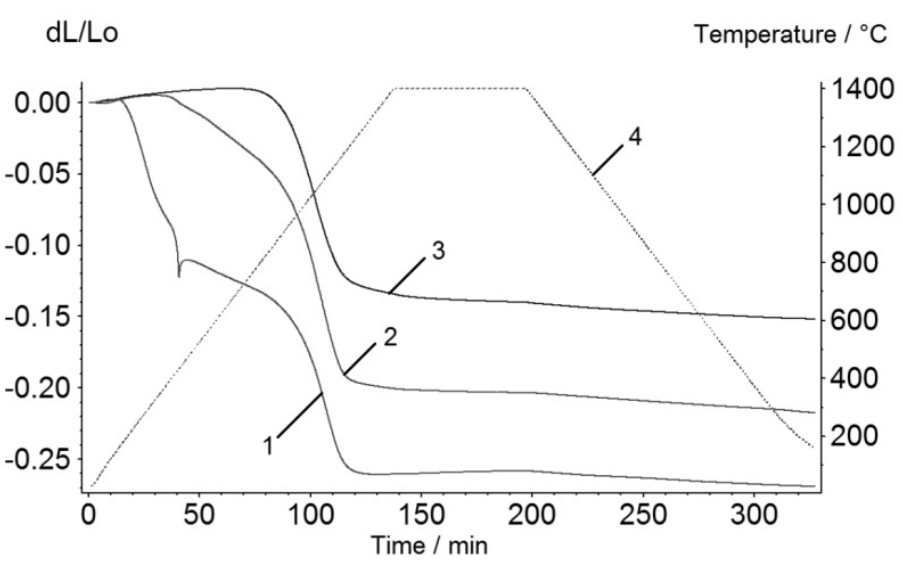

Figure 6. Dilatometric curves for compacts made from powders P1, P2 and P3 (curves 1-3 respectively); curve 4 indicates the annealing temperature regime. The compaction pressure is $460 \mathrm{MPa}$

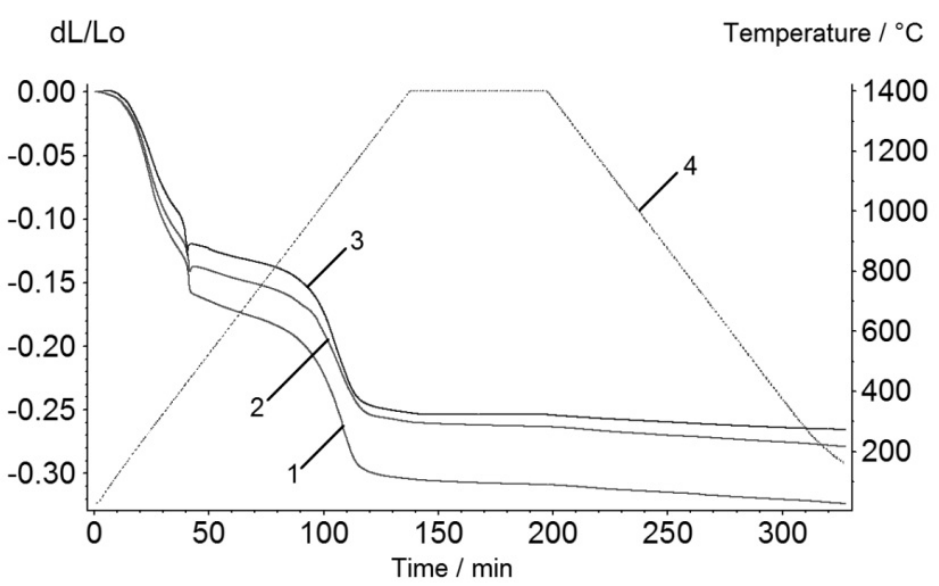

Figure 7. Dilatometric curves for compacts made from powder P1 at compaction pressures of 140, 280 and $460 \mathrm{MPa}$ (curves 1-3 respectively), curve 4 indicates the annealing temperature regime

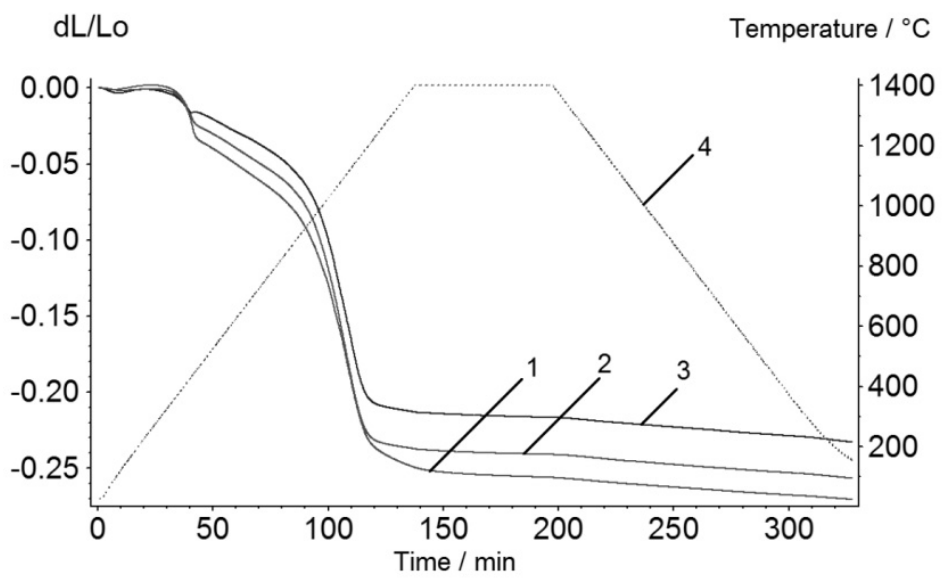

Figure 8. Dilatometric curves for compacts made from powder P2 at compaction pressures of 140, 280 and $460 \mathrm{MPa}$ (curves 1-3 respectively), curve 4 indicates the temperature annealing regime 


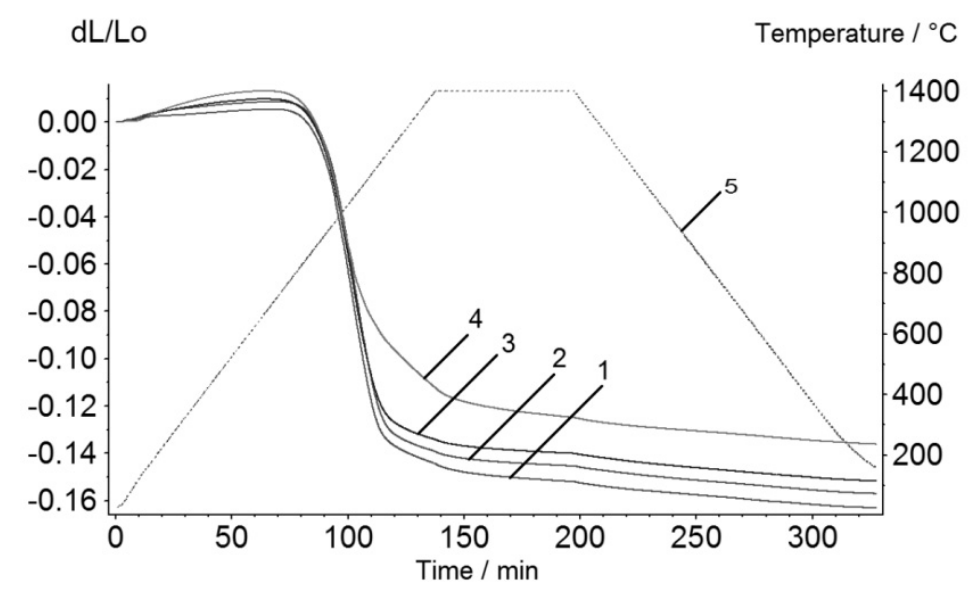

Figure 9. Dilatometric curves for compacts made from powder P3 at compaction pressures of 140, 280, 460 and $925 \mathrm{MPa}$ (curves $1-4$, respectively), curve 5 indicates the annealing temperature regime

Figures 6-9 show that the densification behavior depends on both the powder type (P1, P2 or P3) and the compaction pressure. It is important to note that at the heating stage the densification rate for powder P3 decreases as the compaction pressure grows up. At the stage of isothermal holding, densification is more intensive for compacts produced at higher pressure.

Table 1 presents the density of compacts $\rho p r$, density of ceramics sintered from compacts $\rho$, porosity $\Theta$ and microhardness $\mathrm{Hv}$ for different types of samples depending on compaction pressure Ppr.

$\mathrm{Tab}$ le 1

Dependence of mechanical properties on pressing pressure

\begin{tabular}{|c|c|c|c|c|c|}
\hline $\begin{array}{c}\text { Sample } \\
\text { type }\end{array}$ & $\mathrm{P}_{\mathrm{pr}},[\mathrm{MPa}]$ & $\rho_{\mathrm{pr}},\left[\mathrm{g} / \mathrm{cm}^{3}\right]$ & $\rho_{\mathrm{h}},\left[\mathrm{g} / \mathrm{cm}^{3}\right]$ & $\Theta,[\%]$ & $\mathrm{H}_{\mathrm{v}},[\mathrm{GPa}]$ \\
\hline \multirow{3}{*}{$\mathrm{P} 1$} & 140 & 2.136 & 4.875 & 15.0 & 9.1 \\
\cline { 2 - 6 } & 280 & 2.443 & 5.112 & 9.9 & - \\
\cline { 2 - 6 } & 460 & 2.647 & 5.333 & 5.0 & 8.8 \\
\hline \multirow{3}{*}{ P2 } & 140 & 1.936 & 4.500 & 23.0 & - \\
\cline { 2 - 6 } & 280 & 2.207 & 4.809 & 17.7 & - \\
\cline { 2 - 6 } & 460 & 2.535 & 5.212 & 10.3 & - \\
\hline \multirow{4}{*}{ P3 } & 140 & 2.514 & 3.961 & 31.3 & - \\
\cline { 2 - 6 } & 280 & 2.695 & 4.001 & 26.0 & - \\
\cline { 2 - 6 } & 460 & 2.852 & 4.396 & 24.0 & - \\
\cline { 2 - 6 } & 925 & 3.107 & 4.621 & 20.3 & 9.6 \\
\hline
\end{tabular}

Table 1 shows that other things being equal, the highest density and the lowest porosity were obtained for powder P1 at a compaction pressure of $460 \mathrm{MPa}$. It should be noted that in this case the linear sizes of the samples change most significantly during sintering. For compacts made from powders P2 and P3, the shrinkage is less evident. For ceramics sintered from powders $\mathrm{P} 2$ and P3, the porosity was significantly greater than that for ceramics sintered from powder P1. Therefore, microhardness could not be determined for all the samples [25].

The effect of the sintering mode on the properties of the finished ceramics has been studied for powder P3. The results summarized in Figure 10 show that maximum densification is attained at a heating rate of $10{ }^{\circ} \mathrm{C} / \mathrm{min}$ up to $1400^{\circ} \mathrm{C}$ and holding time of $1 \mathrm{~h}$. The analysis of the experimental data presented in Figure 10 shows that an increased temperature and sintering time and a complicated temperature regime with respect to this sintering mode do not increase the ceramics density. 


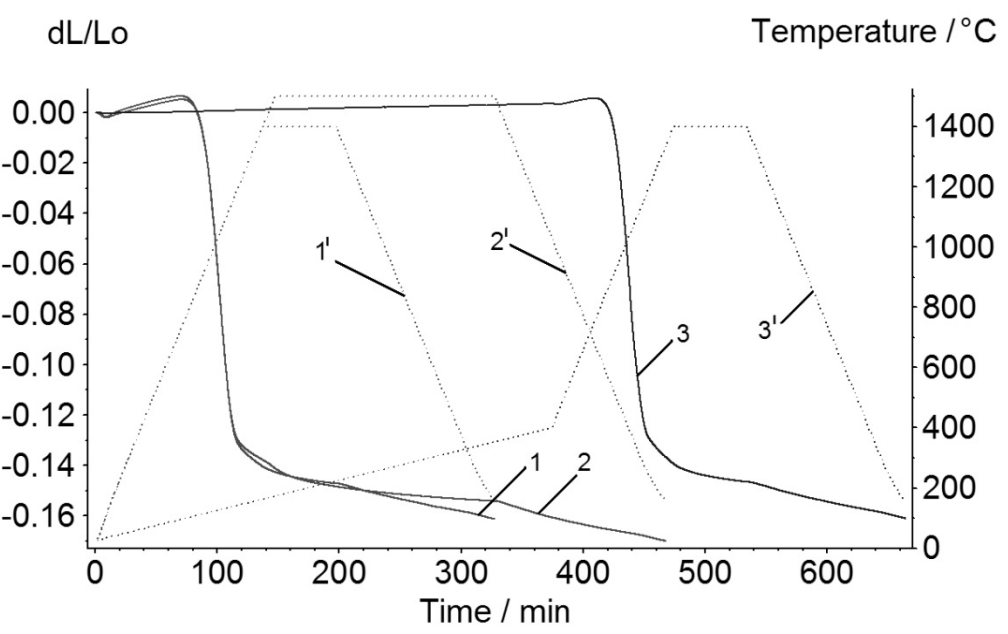

The compaction pressure is $140 \mathrm{MPa} ; 1$ - heating up to $1400^{\circ} \mathrm{C}\left(10^{\circ} \mathrm{C} / \mathrm{min}\right)$, holding for 1 hour; 2 - heating up to $1500{ }^{\circ} \mathrm{C}\left(10^{\circ} \mathrm{C} / \mathrm{min}\right)$, holding for 3 hours; 3 - heating up to $400{ }^{\circ} \mathrm{C}\left(1{ }^{\circ} \mathrm{C} / \mathrm{min}\right)$, heating up to $1400^{\circ} \mathrm{C}\left(10^{\circ} \mathrm{C} / \mathrm{min}\right)$, holding for 1 hour; 11,21 and 31 are temperature annealing regimes, respectively; the cooling rate for all the regimes is $10^{\circ} \mathrm{C} / \mathrm{min}$

Figure 10. Dilatometric curves for compacts from powder P3 sintered in different temperature regimes

\section{Conclusions}

The processes of gas evolution in powder P1 (initial gel) prepared by sol-gel technology and heated in air have been investigated by the methods of thermal analysis. Densification and sintering processes were studied for powder compacts made from initial powder $\mathrm{P} 1$ and after their annealing at 400 and $700{ }^{\circ} \mathrm{C}$ (powders P2 and P3, respectively). The results obtained are as follows.

The heating of initial powder $\mathrm{P} 1$ is followed by the evolution of $\mathrm{NH}_{3}, \mathrm{CO}_{2}$ and $\mathrm{NO}_{2}$ and $\mathrm{NO}$. When the temperature attains $600{ }^{\circ} \mathrm{C}$, the evolution of gases ceases.

Powder $\mathrm{P} 3$ prepared after annealing of initial gel $\mathrm{P} 1$ at $700{ }^{\circ} \mathrm{C}$ is nano-sized, and the particle maximum size does not exceed $20 \mathrm{~nm}$. The powder is characterized by crystalline structure.

Gas adsorbates affect the processes of powder compaction and patterns of compact shrinkage during sintering. They can be regarded as volatile additives that improve the sintering process to produce highdensity ceramics. For initial powder $\mathrm{P} 1$ and powders $\mathrm{P} 2$ and $\mathrm{P} 3$ annealed at $400{ }^{\circ} \mathrm{C}$ and $700{ }^{\circ} \mathrm{C}$, respectively, an increased compaction pressure enhances the ceramics density. At high compaction pressures, gas adsorbates in initial powder P1 have no time to leave the surface of powder grains prior to the formation of closed pores during heating, which can cause the expansion of the sintered sample during isothermal holding. To eliminate this effect, temperature regimes should be chosen to ensure effective evolution of gases at the heating stage. It is important to note that, despite the nanoscale dimensionality of powders P2 and P3, ceramics sintered from them is characterized by high porosity (20-25\%), whereas ceramics sintered from initial powder P1 exhibits porosity of not more than $5 \%$ at compaction pressure of $460 \mathrm{MPa}$. Reduced porosity can be attributed to the presence of volatile additives in initial powder P1, which improve the compaction process during sintering.

Thus, the data obtained show that low-melting additives are promising for the production of highdensity ceramics from partially stabilized zirconia powders prepared by sol-gel technology, which will be another area of future research.

\section{References}

1 Stawarczyk, B., Keul, C., Eichberger, M., Figge, D., Edelhoff, D., \& Lümkemann, N. (2017). Three generations of zirconia: From veneered to monolithic. Part I. J. Quintessence Int., 48, 369-380.

2 Tailor, S., Singh, M., \& Doub, A.V. (2016). Synthesis and characterization of yttria-stabilized zirconia (YSZ) nano-clusters for thermal barrier coatings (TBCs) applications. J. Cluster Sci, 27, 1097-1107. 
3 Freris, I., Riello, P., Enrichi, F., Cristofori, D., \& Benedetti, A. (2011). Synthesis and optical properties of sub-micron sized rare earth-doped zirconia particles. J. Opt. Mater, 33, 1745-52.

4 He, J., Chen, J., Ren, L., Wang, Y., Teng, C., Hong, M., et al. (2014). Fabrication of monodisperse porous zirconia microspheres and their phosphorylation for Friedel-Crafts alkylation of indoles. J. ACS Appl. Mater Interfaces, 6, 2718-2725.

5 Ghosh, A., Koley, S., Sahu, A.K., Kundu, R.T., Ramanathan, S., \& Kothiyal, G.P. (2014). Sintering kinetic study of the nano-crystalline 3-mol\% yttria-samaria codoped tetragonal zirconia polycrystal ceramics. J. Therm. Anal. Calorim, 115(2), 13031310.

6 Cousland, G.P., Cui, X.Y., Smith, A.E., Stampfl, A.P., \& Stampfl, C.M. (2018). Mechanical properties of zirconia, doped and undoped yttria-stabilized cubic zirconia from first-principles. J. Phys. Chem. Solids, 122, 51-71.

7 Zhao, Y., \& Gao, Y. (2017). Structural evolution of plasma-sprayed nanoscale $3 \mathrm{~mol} \%$ and $5 \mathrm{~mol} \%$ yttria-stabilized zirconia coatings during sintering. Appl. Surf. Sci, 425, 1033-1039.

8 O, Y.T., Koo, J.B., Hong, K.J., Park, J.S., \& Shin, D.C. (2004). Effect of grain size on transmittance and mechanical strength of sintered alumina. Mater. Sci. and Eng.: A., 374(1-2), 191-195.

9 Gurt, S.J., Weibel, A., Estournès, C., Yang, Q., Laurent, Ch., \& Peigney, A. (2011). Spark plasma sintering of alumina: Study of parameters, formal sintering analysis and hypotheses on the mechanism(s) involved in densification and grain growth. Acta. Mater, 59(4), 1400-1408.

10 Kuzjukevics, A., Linderoth, S., \& Grabis, J. (1996). Characterization of yttria-doped zirconia powders produced by plasmachemical method. Solid State Ionics, 92(3-4), 253-260.

11 Karpov, I.V., Lepeshev, A.A., Ushakov, A.V., \& Fedorov, L.Y. (2014). Method for producing nanomaterials in the plasma of a low-pressure pulsed arc discharge. J. Tech. Phys, 59(4), 559-563.

12 Dorda, F.A., Dedov, N.V., Korobtsev, V.P., Stepanov, I.A., \& Utkin, S.V. (1997). Patent RU 2076069, C01G25/02

13 Liang, M., Li, F., Ma, X., Kang, Z., Huang, X., \& Wang, X-G., et al. (2016). Syntheses of ZrC-SiC nanopowder via sol-gel method. Ceram. Int., 42(1), 1345-1351.

14 Huang, Q., Yuan, W., Huang, W., Cheng, H., \& Zhou, Y., et al. (2015). Effect of organic additions on the phase composition and crystal growth behavior of $8 \mathrm{wt} \%$ yttria-stabilized zirconia nanocrystals prepared via sol-gel process. J. Sol-Gel Sci. Technol, 74(2), 432-436.

15 Muccillo, E.N.S., Souza, E.C.C., \& Muccillo, R. (2002). Synthesis of reactive neodymia-doped zirconia powders by the solgel technique. J. Alloys Compd, 344(1-2), 175-178.

16 Trusova, E.A., Khrushcheva, A.A., \& Vokhmintcev, K.V. (2012). Sol-gel synthesis and phase composition of ultrafine ceriadoped zirconia powders for functional ceramics. J. Eur. Ceram. Soc, 32(9), 1977-1981.

17 Khare, J., Rajput, P., Joshi, M.P., Jha, S.N., Bhattacharyya, D., \& Kukreja, L.M. (2015). X-ray absorption spectroscopy based investigation of local structure in yttria stabilized zirconia nanoparticles generated by laser evaporation method: Effect of pulsed vs CW mode of laser operation. Ceram. Int., 41(4), 5909-5915.

18 Zeinidenov, A.K., Aimukhanov, A. K., Mukametkali, T. M., Ishmuratova, M.Yu., \& Tleukenova S.U. (2019). Study of spectral and luminescent characteristics of wheat seeds after laser radiation. Bulletin of the Karaganda University. Physics series, 1(93), 26-31.

19 Bardakhanov, S.P., Korchagin, A.I., Kuksanov, N.K., Lavrukhin, A.V., Salimov, R.A., \& Fadeev, S.N., et al. (2007). Use of an electron accelerator to produce nanopowders by evaporation of initial materials at atmospheric pressure. Russ. Phys. J, 50(2), $120-124$.

20 Surzhikov, A.P., Ghyngazov, S.A., Frangulyan, T.S., Vasil'ev, I.P., \& Chernyavskii, A.V. (2017). Investigation of sintering behaviour of $\mathrm{ZrO}_{2}(\mathrm{Y})$ ceramic green body by means of non-isothermal dilatometry and thermokinetic analysis. J. Therm. Anal. Calorim., 128, 787-794.

21 Surzhikov, A.P., Ghyngazov, S.A., Frangulyan, T.S., \& Vasil'ev, I.P. (2015). Thermal transformations in ultrafine plasmochemical zirconium dioxide powders. J. Therm. Anal. Calorim., 119(3), 1603-1609.

22 Kumar, A., Yadav, N., Bhatt, M., Mishra, N.K., Chaudhary, P., \& Singh, R. (2015). Sol-gel derived nanomaterials and it's applications: a review. Res. J. of Chem. Sci, 5(12), 98-105.

23 Zeinidenov, A.K., Ibrayev, N.Kh., \& Aitbaeva, Zh.M. (2015). Development of techniques and methods producing nanostructures porous aluminum oxide by anodic oxidation. Bulletin of the Karaganda University. Physics series, 4(80), $43-47$.

24 Shevelev, S.A., \& Ghyngazov, S.A. (2018). Effect of additives on sintering of zirconia ceramics. J. Therm. Anal. Calorim., 134(1), 45-49, DOI: 10.1007/s10973-018-7249-0

25 Toleuov, G., Isataev, M.S., Seidulla, Zh.K., Dosanova, A., \& Tolen, Zh. (2019). Experimental study of free turbulent jet. Bulletin of the Karaganda University. Physics series, 1(93), 79-86, DOI: 10.31489/2019Ph1/79-86.

\section{Е. Шевелева, С. Шевелев, А. Соколовский, А.К. Зейниденов}

\section{Золь-гель технологиясы арқылы алынған газ бөлуді және цикроний диоксидінің наноұнтағын құюды термиялық талдау әдісімен зерттеу}

Золь-гель технологиясы бойынша алынған цирконий диоксидінің жартылай тұрақтандырылған ұнтақтары үшін термиялық және рентгенқұрылымдық талдау әдістерін пайдалана отырып, ауада сығу кезінде газ бөлу процестері мен осы ұнтақтарды жинастыру және кейін құю кезінде тығыздаудың заңдылықтары зерттелген. Бастапқы гельдің ұнтақтарында көп мөлшерде газ адсорбаттары бар екендігі анықталған. Олардың саны күйдіру температурасының жоғарылауына қарай азаяды. $700{ }^{\circ} \mathrm{C}$ 
күйдіру температурасы кезінде ұнтақтар адсорбаттардан толықтай құтылып, тетрагоналды фазалы кристалды құрылымды қабылдайды. Газ адсорбаттары пісіру кезінде ұнтақты жинағыштардың тығыздауына әсер етеді. Олардың болуы $5 \%$-дан аспайтын кеуектілігі бар керамиканы алуға мүмкіндік береді. Өртеуге ұшыраған ұнтақтардан қоспалардың болмауы мен наноөлшеміне қарамастан, төмен кеуекті қыш алу қиынға соғады. Оны алу үшін жеңіл балқитын қоспаларды пайдалану ұсынылған.

Кілт сөздер: цирконий диоксид наноұнақтары, золь-гель әдісі, газ адсорбаттары, дилатометрия.

\section{Е. Шевелева, С. Шевелев, А. Соколовский, А.К. Зейниденов}

\section{Исследование методами термического анализа газовыделения и спекания нанопорошков диоксида циркония, полученных по золь-гель технологии}

С использованием методов термического и рентгеноструктурного анализов для порошков частично стабилизированного диоксида циркония, полученных по золь-гель технологии, исследованы процессы газовыделения при отжиге на воздухе и закономерности уплотнения этих порошков при компактировании и последующем спекании. Установлено, что порошки исходного геля содержат большое количество газовых адсорбатов. Их количество уменьшается по мере повышения температуры отжига. При температуре отжига $700{ }^{\circ} \mathrm{C}$ порошки полностью освобождаются от адсорбатов и принимают кристаллическую структуру с преимущественно тетрагональной фазой. Газовые адсорбаты влияют на уплотнение порошковых компактов во время спекания. Их присутствие способствует получению керамики с пористостью не более 5 \%. Показано, что, несмотря на наноразмерность и отсутствие примесей из порошков, подвергнутых отжигу, затруднительно получить низкопористую керамику. Для ее получения предложено использование легкоплавких добавок.

Ключевые слова: нанопорошки диоксида циркония, золь-гель метод, газовые адсорбаты, дилатометрия. 